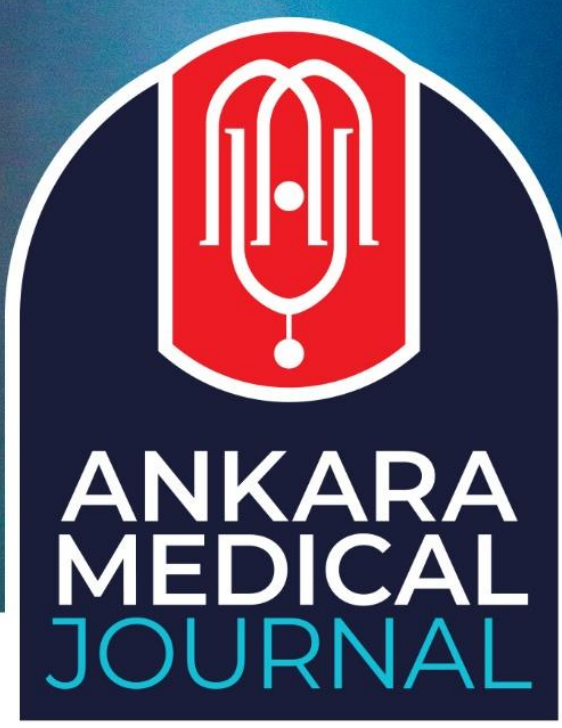

Research Article

Ankara Med J, 2021;(3):494-502 // (đi) 10.5505/amj.2021.06926

\title{
COMPLEMENTARY AND ALTERNATIVE MEDICINE USE IN TYPE 2 DIABETES MELLITUS AND ITS RELATIONSHIP WITH MEDICATION ADHERENCE
}

\section{TİP 2 DİABETES MELLİTUS’TA TAMAMLAYICI ALTERNATİF TIP KULLANIMI VE TEDAVİ UYUMU İLE İLISKISİ}

(D) Cemal Uyan' ${ }^{1}$, (D) Tuncay Müge Alvur ${ }^{1}$

${ }_{1}^{1}$ Department of Family Medicine, Kocaeli University Faculty of Medicine, Kocaeli, Turkey

Yazıșma Adresi / Correspondence:

Cemal Uyan (e-mail: cemaluyan03@gmail.com)

Geliş Tarihi (Submitted): 06.07.2020 // Kabul Tarihi (Accepted): 01.02.2021

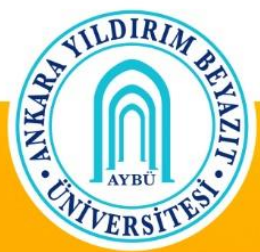

Ankara Yildırım Beyazıt University Faculty of Medicine 


\title{
Öz
}

Amaç: Bu çalışmada, Tip 2 Diabetes Mellitus'ta (T2DM) tamamlayıcı ve alternatif tıp (TAT) kullanımını ve bunun uzun süreli medikal tedaviye uyum ile ilişkisini araştırmayı amaçladık.

Materyal ve Metot: Araştırma, tanımlayıcı tipte bir çalışma olarak tasarlandı. En az 1 yıldır oral antidiyabetik kullanan 100 hasta çalışmaya dahil edildi. Katılımcılara, sosyodemografik özellikleri ve TAT kullanımını sorgulayan bir anket; tedaviye uyumu ölçmek için 6 soruluk Türkçe Modifiye Morisky Ölçeği uygulandı.

Bulgular: Hastaların \%55'i en az bir TAT yöntemi kullanmıştı. En sık kullanılan yöntem bitkisel ilaçlar $(\% 80(n=44))$ idi. TAT yöntemleri başlıca, şikayetleri azaltmak ve tedaviyi destekleyici amaçlı kullanılmış ve hastaların \%85,5'i (n=47) bu yöntemlerin kullanımı konusunda doktora danışmamıștı. Bu hastaların \%89,4'ü $(\mathrm{n}=42)$ danışmama nedenini, 'doktorun olumsuz tepkisinden çekinme' olarak belirtti. TAT kullanımı ile tedaviye uyum arasında istatistiksel olarak anlamlı ilişki bulunmadı.

Sonuç: Hastaların TAT yöntemlerini kullanırken doktora danışmamaları, ilaç-bitki etkileşimlerine bağlı toksikasyonlara ve doz yetersizliklerine karşı dikkatli olmamız gerektiğini göstermektedir. Hekimler hastalarının ilaç öyküsü yanında bu yöntemlerin kullanımını da etkin bir şekilde sorgulamalıdır. Bu bağlamda, tüm hekimler TAT yöntemleri hakkında temel bilgiye sahip olmalı ve bu tedaviler hakkında kanıta dayalı bilgiye nasıl ulaşılabileceklerini de öğrenmelidir.

Anahtar Kelimeler: Tedavi uyumu, diabetes mellitus, tamamlayıcı terapiler, alternatif tıp.

\begin{abstract}
Objectives: In this study, we aimed to investigate complementary and alternative medicine (CAM) use and its relationship with adherence to long-term medical therapy in Type 2 Diabetes Mellitus (T2DM).

Materials and Methods: The research was designed as a descriptive study. 100 (a hundred) patients who were using oral antidiabetic for at least one year were included in the study. A questionnaire to determine sociodemographic characteristics and CAM use and a six-item Turkish Modified Morisky Scale for the measure of medication adherence were applied to the participants.

Results: $55 \%$ of patients ( $n=55)$ used at least one CAM practice. The most commonly used practice was herbal medicine $[80 \%(n=44)]$. The main reasons for using CAM were to relieve complaints and support their conventional treatment, and $85.5 \%(n=47)$ of patients did not consult their physicians about the use of these practices. There was no statistically significant relationship between CAM use and medication adherence.

Conclusion: The fact that patients do not consult a doctor while using CAM shows that we need to be careful about toxicities and dose insufficiency due to drug-herb interactions. Physicians should effectively investigate the use of these therapies in addition to the drug history of their patients. Therefore, all physicians should have at least basic knowledge of CAM and learn how to access evidence-based information about these practices. Keywords: Medication adherence, diabetes mellitus, complementary therapies, alternative medicine.
\end{abstract}




\section{Introduction}

There has been an ever-increasing rise in the use of Complementary and Alternative Medicinal (CAM) practices among general populations during the past few decades. Individuals with diabetes, being prone to an array of related health complications, demand special attention concerning their interest in different CAM practices. ${ }^{1,2}$ Since diabetes is a disease resulting in a huge economic burden, physical and mental disability, and all patients should have the privilege of receiving effective therapies with the least adverse effects. According to a study conducted on the prevalence and pattern of complementary and alternative medicine use, individuals with diabetes are approximately 1.6 times more likely to use CAM therapies than people without diabetes. ${ }^{3}$ The reasons why patients tend to use CAM practices are widely discussed but not well understood. Moreover, it was observed that patients who were using CAM did not consult their physicians in general. ${ }^{4} \mathrm{~A}$ vast majority of patients opt for CAM therapies as a complement to conventional care rather than as an alternative choice. ${ }^{5}$

Poor treatment adherence is an important problem that increases mortality and morbidity in chronic diseases. Several rigorous reviews have found that, in developed countries, adherence among patients suffering chronic diseases averages only $50 \%{ }^{6}$ The magnitude and impact of poor adherence in developing countries are assumed to be even higher given the paucity of health resources and inequities in access to health care. This seriously and adversely affects the treatment efficacy, especially in long-term therapies. ${ }^{7}$ Numerous studies have explored potential predictors of adherence to medicine across various conditions. Frequently cited predictors include unmodifiable variables such as age, sex, ethnicity, income, education, and comorbidity. ${ }^{8}$ Thus, this study aimed to characterize complementary and alternative medicine (CAM) use and assess its relationship with adherence to long-term oral therapy in the T2DM population.

\section{Materials and Methods}

The population of this descriptive study was 435 individuals who applied to the Diabetes Outpatient Clinic of Kocaeli University Faculty of Medicine Hospital in the December 2018- January 2019 period with T2DM who were treated with just oral agents for at least one year. One hundred twenty-three people were invited to the questionnaire; two illiterate, eight hearing-speech problems, and 13 unwilling patients were excluded, and the study was completed with 100 participants. Patients were informed about the study, and their consent was obtained, and the questionnaire was administered face to face with willing patients in the outpatient clinic setting.

The data were collected by a questionnaire comprised four main sections, exploring: (1) sociodemographic characteristics; (2) medication-taking behaviors; (3) Turkish Modified Morisky Scale (TMMS) with six questions to measure treatment adherence; (4) CAM questionnaire contained 15 questions related to CAM 
methods used by patients, their sources of information, purposes of use and informing their doctors. The CAM questionnaire has not been carried out for those who stated that they have never used any CAM practices for their diseases.

Morisky scale to measure the patients' adherence to medical treatment in chronic diseases are easily applicable and reliable, which can evaluate motivation and level of knowledge separately. Also, it was concluded that it would be useful to assess adherence to long-term pharmacological treatment of chronic illnesses in primary care. ${ }^{9}$ The scale consists of six questions, reflecting five domains: forgetfulness, carelessness; knowledge of long-term therapy; the impact of feeling well on adherence; and the impact of feeling poorly on adherence. Patients with a score of 4 or above were classified as 'treatment adherent; those with a score of 3 or below were classified as 'treatment nonadherent' or 'poor treatment adherent'. Patients who used CAM for chronic diseases at any time were classified as CAM users.

Statistical analyses of the data were carried out using SPSS software (Version 22.0, SPSS Inc., Chicago, IL, USA). Chi-square tests were used for the analysis of the relationships between categorical variables, independent samples t-test, or Mann-Whitney U test (for non-parametric data) for continuous variables. Results are reported as mean \pm SD or $\mathrm{n}(\%)$. All statistical tests were two-sided, and differences were accepted as significant at $\mathrm{p}<0.05$.

\section{Results}

The mean age of the patients included in our study was $58.56 \pm 8.88$ years, and the age range was 33-84. Fifty of the participants were female (50\%), and fifty were male (50\%). There were no significant differences in age, gender, education, and duration of diabetes between CAM and non-CAM users (Table 1). 56.36\% ( $\mathrm{n}=31$ ) of the 55 patients who stated that they used at least one CAM practices for any chronic disease used these practices for their diabetes, $69.09 \%(n=38)$ for non-diabetic reasons, $25.45 \%(n=14)$ for both diabetes and non-diabetic reasons (Figure 1). There was no overall difference in treatment adherence between CAM and non-CAM users. When the use of CAM for any reason or diabetes was examined separately, no significant difference was found between the adherence (Table 2). The most common reason cited for using CAM was to relieve complaints. When we investigated these symptoms, the pain was the first, and the high blood glucose level was the second. Another common reason for using CAM was found to support the conventional treatment. These results are summarized in the table below (Table 3). 
Table 1. Demographic and clinical characteristics by CAM use status

\begin{tabular}{|c|c|c|c|}
\hline & CAM (n=55) & No CAM $(n=45)$ & p value \\
\hline Age [mean \pm SD] & $57.87 \pm 9.23$ & $59.40 \pm 8.46$ & 0.395 \\
\hline \multicolumn{4}{|l|}{ Gender [n (\%)] } \\
\hline Male & $27(54)$ & $23(46)$ & \multirow[b]{2}{*}{1.000} \\
\hline Female & $28(56)$ & $22(44)$ & \\
\hline \multicolumn{4}{|l|}{ Education [n (\%)] } \\
\hline Literate & $4(44.44)$ & $5(55.55)$ & \multirow{4}{*}{0.746} \\
\hline Primary & $23(58.97)$ & $16(41.03)$ & \\
\hline Secondary & $7(63.64)$ & $4(3.36)$ & \\
\hline College-High School & $21(51.22)$ & $20(48.78)$ & \\
\hline \multicolumn{4}{|c|}{ Duration of diabetes [n (\%)] } \\
\hline $1-5$ years & $10(25)$ & $30(75)$ & \multirow{4}{*}{0.716} \\
\hline $6-10$ years & $12(34.28)$ & $23(65.72)$ & \\
\hline 11-19 years & $6(33.33)$ & $12(66.66)$ & \\
\hline 20 and + & $3(42.86)$ & $4(57.14)$ & \\
\hline
\end{tabular}

$80 \%(n=44)$ of CAM users used at least one of the herbal remedies. Cinnamon $(n=24)$, herbal teas $(n=15)$ and black seed $(n=13)$ were the most commonly used herbal remedies. When we look at the use of traditional practices, it was seen that five people used acupuncture, two people used dry cupping, 15 people used wet cupping (hijamah), and six people used leeches (Table 4). 14.5\% ( $\mathrm{n}=8)$ of CAM users consulted physicians for the use of these practices; in contrast, $85.5 \%(n=47)$ of them did not. $89.4 \%(n=42)$ of these patients stated that the reason for not consulting was 'afraid of the negative reaction of the doctor' (Table 5).

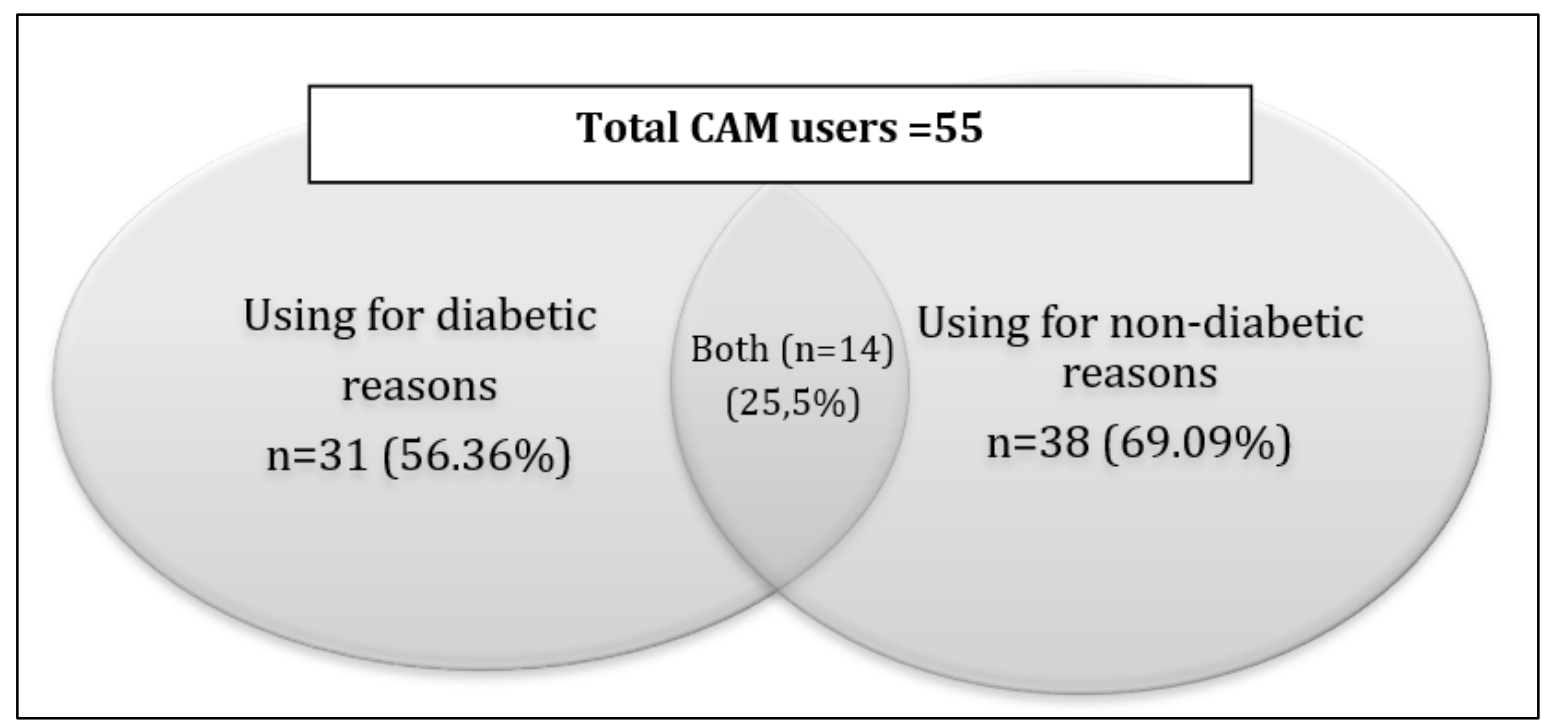

Figure 1. Reasons for CAM usage 
Table 2. Adherence to medication by CAM status

\begin{tabular}{|c|c|c|c|}
\hline \multicolumn{4}{|c|}{ CAM use for any reason } \\
\hline & $\begin{array}{c}\text { Yes } \\
(n=55)\end{array}$ & $\begin{array}{c}\text { No } \\
(n=45)\end{array}$ & p value \\
\hline Adherent (n=71) & $39(70.91)$ & $32(71.11)$ & \multirow{2}{*}{1.000} \\
\hline Non-adherent $(n=29)$ & $16(29.09)$ & $13(28.89)$ & \\
\hline \multicolumn{4}{|c|}{ CAM use for T2DM } \\
\hline & $\begin{array}{c}\text { Yes } \\
(n=31)\end{array}$ & $\begin{array}{c}\text { No } \\
(n=69)\end{array}$ & p value \\
\hline Adherent (n=71) & $21(67.74)$ & $50(72.46)$ & \multirow{2}{*}{0.630} \\
\hline Non-adherent $(n=29)$ & $10(32.26)$ & $19(27.54)$ & \\
\hline
\end{tabular}

Table 3. Purposes of CAM use

\begin{tabular}{|c|c|c|c|}
\hline Reason for CAM use & Yes n (\%) & No n (\%) & Total n (\%) \\
\hline Relieve complaints & $38(69.09)$ & $17(30.91)$ & $55(100)$ \\
\hline \multicolumn{4}{|l|}{ Complaints } \\
\hline Pain & $15(39.47)$ & $23(60.53)$ & $38(100)$ \\
\hline High Blood Glucose & $11(28.95)$ & $27(71.05)$ & $38(100)$ \\
\hline Other & $12(31.58)$ & $26(68.42)$ & $38(100)$ \\
\hline As supportive treatment & $23(41.82)$ & $32(58.18)$ & $55(100)$ \\
\hline Reduce to adverse effects of medication & $2(3.64)$ & $53(96.36)$ & $55(100)$ \\
\hline Support to immunity & $8(14.55)$ & $47(85.45)$ & $55(100)$ \\
\hline Replace medical treatment & $5(9.09)$ & $50(90.91)$ & $55(100)$ \\
\hline To relax psychologically & $4(7.27)$ & $51(92.73)$ & $55(100)$ \\
\hline To do everything against the disease & $5(9.09)$ & $50(90.91)$ & $55(100)$ \\
\hline
\end{tabular}

Table 4. Used CAM practices

\begin{tabular}{|l|c|}
\hline CAM practice & Users n (\%) \\
\hline Herbal remedies & $44(80)$ \\
\hline Acupuncture & $5(9.09)$ \\
\hline Dry cupping & $2(3.64)$ \\
\hline Wet cupping (hijamah) & $15(27.27)$ \\
\hline Leeches & $6(10.91)$ \\
\hline Multivitamins & $2(3.64)$ \\
\hline Other (Ozone therapy, honey, probiotics) & $3(5.45)$ \\
\hline
\end{tabular}


Table 5. Consultation the use of CAM with the physician

\begin{tabular}{|l|c|c|c|}
\hline \multicolumn{2}{|c|}{ Physician Consultation Status } & n (\%) & Total n (\%) \\
\hline \multirow{3}{*}{ Yes } & Approved my use & $4(50)$ & \multirow{2}{*}{$8(14.55)$} \\
\cline { 2 - 3 } & Did not approve & $1(12.50)$ & \multirow{2}{*}{$47(85.45)$} \\
\hline \multirow{3}{*}{ No } & No ideas & $3(37.50)$ & $55(100)$ \\
\hline Total & I was afraid of negative reaction & $42(89.36)$ & $5(10.64)$ \\
\hline
\end{tabular}

\section{Discussion}

Complementary and Alternative Medicine (CAM) use is increasing worldwide. This increase is thought to be mostly associated with the increase in chronic diseases such as diabetes ${ }^{10,11}$. CAM users with diabetes often think that CAM therapies are safe when used in combination with conventional therapies. ${ }^{12}$

In a review of 13 studies investigating the relationship between diabetes and CAM, the rate of CAM use ranged from $30.5 \%$ to $92.9 \% .^{13}$ The frequency of CAM use in our study was consistent with the literature. In studies, although the use of any CAM method in diabetic patients was found to be significantly higher than in the general population, patients mostly used these practices for non-diabetes conditions. ${ }^{14,15} \mathrm{Also}$, in our study, use for nondiabetes purposes was found to be more frequent.

Conflicting results have been reported regarding the relationship between CAM use and adherence to medical treatment. While numerous risk factors for non-adherence have been identified, the role of CAM use and its impact on adherence to conventional medicine is uncertain. It is known that the more medication a patient uses, the less likely the patient is to be adherent to a medication regimen; hence, the addition of CAM could lower medication adherence. ${ }^{16,17}$ Our study aimed to investigate this relationship in patients with T2DM. In a study of 196 hypertensive patients in the UK, it was indicated that being a CAM user is significantly associated with imperfect adherence to antihypertensive medication. ${ }^{18}$ On the other hand, in a retrospective study of 300 patients at least sixty-five years of age who used at least three medications, no association was found between the use of at least one complementary medicine and adherence to conventional medications. ${ }^{17}$ In a study conducted by Bailey et al., it was shown that the use of CAM is one of the less common barriers to medication adherence in patients with diabetes. ${ }^{19} \mathrm{~A}$ study which was conducted with 114 diabetic patients in Indonesia demonstrated that CAM usage significantly decreases adherence to prescribed diabetes medication. ${ }^{20}$

Even in the developed countries, the rate of treatment adherence was reported to be around $50 \%$; this rate in our study was $71 \%$, which was surprisingly higher than expected. Such high rates of patients' adherence may mask the difference between CAM users and non-users. Although the frequency of consultation with physicians 
varies between $16.3 \%$ and $63.2 \%$, patients often tend to hide that they used CAM. ${ }^{13,21,22}$ In 2001, the American Diabetes Association (ADA) issued a position statement on "unproven therapies" encouraging health care providers to ask their patients about alternative therapies and practices, evaluate each therapy's effectiveness, be cognizant of any potential harm to patients, and acknowledge circumstances in which new and innovative diagnostic or therapeutic measures might be provided to patients. ${ }^{23}$ In our study, it was noteworthy that the reason for not consulting was 'afraid of the negative reaction of the doctor'. In this context, it is seen that the physician should question the use of CAM in good communication and cooperation. As a consequence of such attitudes, there will not be any problem that the patients are afraid of the negative reaction of the doctor. ADA's advice is also in this sense.

This study is one of the few studies investigating the relationship between CAM use and adherence in T2DM patients. This is a superior aspect of our study. There are several limitations to this study. First, the data were based on the respondents' self-reported medication adherence and CAM usage, thus may have been affected by recall bias. Second, the study did not include patients' clinical data, which could help identify the effect of CAM use on their physiology.

Our results may be interpreted as the majority of patients perceive these practices as complementary and supportive rather than as an alternative to conventional medication. In our study, despite the contrary results, treatment adherence is a multidimensional phenomenon, and it should be kept in mind that it may be affected by many factors, including the use of CAM. Therefore, each patient should be assessed individually. On the other hand, the fact that patients do not consult a doctor while using herbal remedies indicates that we need to be careful about toxicities and dose insufficiency due to drug-herb interactions. All physicians, especially in primary care, should consider CAM practices without any prejudice and should have basic knowledge of these practices at least related to their specialty. This will play a vital role in guiding patients correctly. In this context, courses about complementary and alternative therapies should be added to medicine school curriculums, and these courses should continue even after graduation. Moreover, physicians should be instructed on how to obtain evidence-based information about these therapies.

\section{Ethical considerations}

The study was approved by the Kocaeli University Faculty of Medicine Ethics Committee (No: 2018/15.6).

\section{Conflict of interest}

The authors declare no conflict of interest. 


\section{References}

1. Şahin A, Dirgar E, Olgun N. Diyabet Yönetiminde Kullanılan Tamamlayıcı ve Alternatif Tedaviler. Diyabet, Obezite ve Hipertansiyonda Hemşirelik Forumu Derg. 2019;11(1):32-6.

2. Kesavadev J. Efficacy and safety concerns regarding Complementary and Alternative Medicine use among diabetes patients. JPMA J Pak Med Assoc. 2017;67(2):316-9.

3. Egede LE, Ye X, Zheng D, Silverstein MD. The prevalence and pattern of complementary and alternative medicine use in individuals with diabetes. Diabetes Care. 2002;25(2):324-9.

4. Lee M-S, Lee MS, Lim H-J, Moon S-R. Survey of the use of complementary and alternative medicine among Korean diabetes mellitus patients. Pharmacoepidemiol Drug Saf. 2004;13(3):167-71 (doi:10.1002/pds.877).

5. Barnes PM, Bloom B, Nahin RL. Complementary and alternative medicine use among adults and children: United States, 2007. Natl Health Stat Rep. 2008;(12):1-23.

6. Haynes RB, McDonald H, Garg AX, Montague P. Interventions for helping patients to follow prescriptions for medications. Cochrane Database Syst Rev. 2002;(2):CD000011 (doi:10.1002/14651858.CD000011).

7. Sabaté E, World Health Organization, eds. Adherence to Long-Term Therapies: Evidence for Action. World Health Organization; 2003.

8. Osterberg L, Blaschke T. Adherence to Medication. $N$ Engl J Med. 2005;353(5):487-97 (doi:10.1056/NEJMra050100).

9. Vural B, Acar ÖT, Topsever P, Filiz TM. Reliability and validity of Turkish version of modified Morisky scale. J Turk Fam Physician. 2012;3(4):17-20.

10. Kumar D, Bajaj S, Mehrotra R. Knowledge, attitude and practice of complementary and alternative medicines for diabetes. Public Health. 2006;120(8):705-11 (doi:10.1016/j.puhe.2006.04.010).

11. Şahin S. Geleneksel, tamamlayıcl, alternatif tıp uygulamalarına genel bir bakış. Türkiye Aile Hekim Derg. 2017;21(4):159-62 (doi:10.15511/tahd.17.00459).

12. Metcalfe A, Williams J, McChesney J, Patten SB, Jetté N. Use of complementary and alternative medicine by those with a chronic disease and the general population - results of a national population based survey. BMC Complement Altern Med. 2010;10(1):58 (doi:10.1186/1472-6882-10-58).

13. Calik A. Complementary and alternative treatments used in the treatment of diabetes: literature review. Adnan Menderes Üniversitesi Sağlık Bilim Fakültesi Derg. 2017;1(2):79-84.

14. Bell RA, Suerken CK, Grzywacz JG, Lang W, Quandt SA, Arcury TA. Complementary and alternative medicine use among adults with diabetes in the United States. Altern Ther Health Med. 2006;12(5):16-22. 
15. Fabian E, Töscher S, Elmadfa I, Pieber TR. Use of complementary and alternative medicine supplements in patients with diabetes mellitus. Ann Nutr Metab. 2011;58(2):101-108. doi:10.1159/000326765

16. Claxton AJ, Cramer J, Pierce C. A systematic review of the associations between dose regimens and medication compliance. Clin Ther. 2001;23(8):1296-310 (doi:10.1016/S0149-2918(01)80109-0).

17. Cherniack EP. Complementary medicine use is not associated with non-adherence to conventional medication in the elderly: A retrospective study. Complement Ther Clin Pract. 2011;17(4):206-8 (doi:10.1016/j.ctcp.2010.11.005).

18. Gohar F, Greenfield SM, Beevers DG, Lip GYH, Jolly K. Self-care and adherence to medication: a survey in the hypertension outpatient clinic. BMC Complement Altern Med. 2008;8:4 (doi:10.1186/14726882-8-4).

19. Bailey GR, Barner JC, Weems JK, et al. Assessing barriers to medication adherence in underserved patients with diabetes in Texas. Diabetes Educ. 2012;38(2):271-279. doi:10.1177/0145721711436134

20. Alfian SD, Sukandar H, Arisanti N, Abdulah R. Complementary and alternative medicine use decreases adherence to prescribed medication in diabetes patients. Ann Trop Med Public Health. 2016;9(3):174 (doi:10.4103/1755-6783.179108).

21. Lee GBW, Charn TC, Chew ZH, Ng TP. Complementary and alternative medicine use in patients with chronic diseases in primary care is associated with perceived quality of care and cultural beliefs. Fam Pract. 2004;21(6):654-60 (doi:10.1093/fampra/cmh613).

22. Güven ŞD. Diabetus Mellituslu Bireylerin Tamamlayıcı ve Alternatif Tedavi Kullanma Durumları. Nevşehir Bilim Ve Teknol Derg. 2020;9(1):1-8 (doi:10.17100/nevbiltek.694483).

23. Payne C. Complementary and Integrative Medicine: Emerging Therapies for Diabetes, Part 1: Preface. Diabetes Spectr. 2001;14(3):129-31 (doi:10.2337/diaspect.14.3.129). 